\title{
SEISMICITY OF FENNOSCANDIA IN RELATION TO COSMIC CONDITIONS
}

\author{
G. P. TAMRAZYAN
}

Institute of Geology, Academy of Sciences of the Azerbaijanian SSR.

This paper deals with the distribution of earthquakes in Fennoscandia in connection with cosmic conditions. Considerad here are earthquakes of a magnitude $\mathrm{M} \geqslant 3$ from 1900-1950 (data from Markus Båth, 1956). Within these 50 years 269 earthquakes were registered (Fig. 1). Comparatively strong earthquakes (magnitude $\mathrm{M} \geqslant 4$ ) during this period are shown in Table 1 . The strongest earthquake in Fennoscandia on 23rd October 1904 had a magnitude of $\mathrm{M}=6.5$ and the quantity of energy released was $3.5 \times 10^{21} \mathrm{erg}$. All the other earthquakes taken together released only $5.4 \times 10^{20} \mathrm{erg}$, which is almost 6.5 times less. In order not to obscure the picture of the distribution of seismic energy of all the earthquakes in Fennoscandia, this strongest earthquake ( $M=6.5)$ is excluded from the following statistical account. As seen in Table 2 the 74 earthquakes with a magnitude of $M \geqslant 4$ released slightly more than $95 \%$ of the energy of all the earthquakes recorded in Fennoscandia (19001950). The remaining 195 earthquakes with a magnitude of $\mathrm{M}=3.0-3.9$ released less than $5 \%$ of the total seismic energy in Fennoscandia. The energy released by earthquakes of lesser magnitude $(\mathrm{M}<3)$ is insignificant. On the whole, 74 strong earthquakes form the seismic picture of the region.

In order to analyse the seismic material, it has been necessary in the following to use some conventional terms, such as the synodic and reduced anomalistic age of the earthquakes as well as the reduced lunar days.

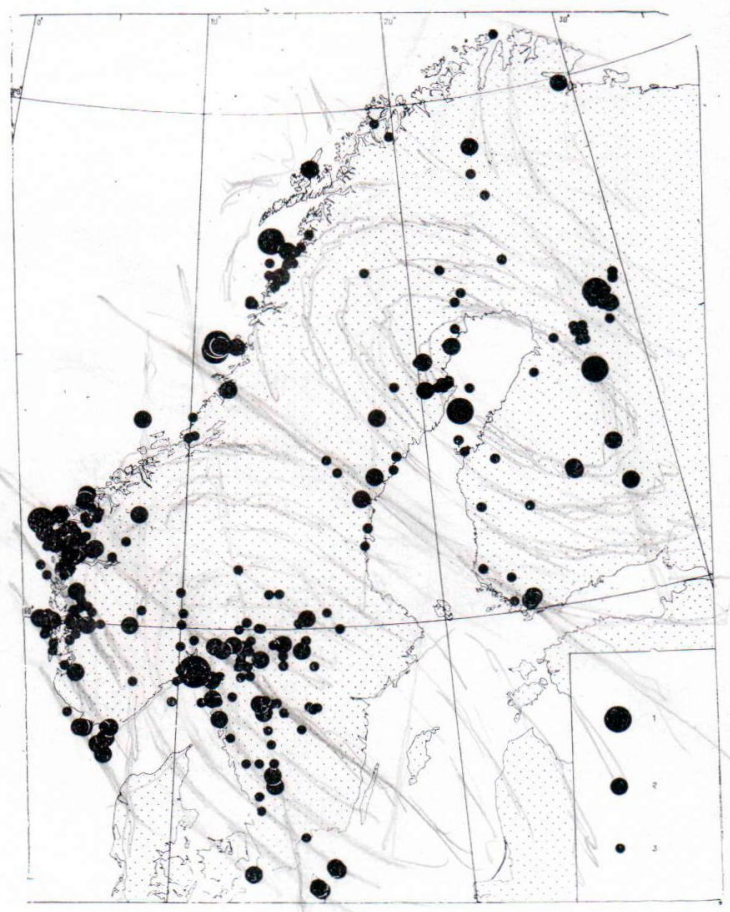

Fig. 1. Earthquakes in Fennoscandia (1900-1950). Earthquake magnitude (M): 1) $5.0-5.4$ or more: 2) $4.0-4.9$ : 3) $3.0-3.9$. 
TABLE 1

The strong earthquakes (with magnitude $M \gg 4$ ) in Fennoscandia for the period 1900-1950, their synodic and reduced anomalistic ages and reduced lunar time

\begin{tabular}{|c|c|c|c|c|c|c|c|c|}
\hline No. & Date & $\begin{array}{c}\text { Greenwich } \\
\text { Mean } \\
\text { Time } \\
\text { (hours, } \\
\text { minutes) }\end{array}$ & $\begin{array}{l}\text { Lati- } \\
\text { tude } \\
\mathrm{N}\end{array}$ & $\begin{array}{l}\text { Longi- } \\
\text { tude } \\
\mathrm{E}\end{array}$ & $\begin{array}{l}\text { Magni- } \\
\text { tude } \\
\mathrm{M}\end{array}$ & $\begin{array}{c}\text { Synodic age } \\
\text { of the earth- } \\
\text { quake } \\
\text { (days, hours) }\end{array}$ & $\begin{array}{c}\text { Reduced } \\
\text { anomalistic } \\
\text { age of the } \\
\text { earthquake } \\
\text { (days) }\end{array}$ & $\begin{array}{c}\text { Reduced } \\
\text { local } \\
\text { lunar } \\
\text { time } \\
\text { (hours) }\end{array}$ \\
\hline 1 & 2 & 3 & 4 & 5 & 6 & 7 & 8 & 9 \\
\hline 1 & November 5, ..... 1901 & 2258 & 59.7 & 13.8 & 4. 7 & 2418 & 9.0 & 15.8 \\
\hline 2 & April $10, \ldots \ldots \ldots 1902$ & 1930 & 64.3 & 27.6 & 5.2 & 217 & 0.7 & 7.1 \\
\hline 3 & April $29, \ldots \ldots \ldots \ldots 1902$ & 1315 & 57.2 & 13.4 & 4. 0 & 2114 & 19.0 & 8.7 \\
\hline 4 & September 4, . . . . 1902 & 900 & 65.5 & 11.0 & 4.5 & 215 & 7.0 & 19.7 \\
\hline 5 & October 23, ...... 1904 & 1027 & 59.2 & 10.5 & 6.5 & 1318 & 15.2 & 12.1 \\
\hline 6 & November $18, \ldots \ldots 1904$ & 230 & 59.6 & 11.5 & 4. 7 & 1023 & 13.0 & 6.3 \\
\hline 7 & December $13, \ldots \ldots \ldots 1904$ & 2151 & 58.7 & 11.3 & 4. 2 & 706 & 12.4 & 4.7 \\
\hline 8 & February $6, \ldots \ldots \ldots 1905$ & 1710 & 62.0 & 5.0 & 4.7 & 217 & 14.1 & 3.2 \\
\hline 9 & June $3, \ldots \ldots \ldots \ldots 1906$ & 324 & 58.0 & 6.5 & 4.3 & 1107 & 25.0 & 6.7 \\
\hline 10 & December $10, \ldots \ldots 1906$ & 1611 & 58.0 & 6.5 & 4.2 & 2423 & 23.2 & 8.4 \\
\hline 11 & January $10, \ldots \ldots \ldots 1907$ & 032 & 59.6 & 12.3 & 4.9 & 2520 & 25.0 & 16.4 \\
\hline 12 & January $14, \ldots \ldots \ldots 1907$ & 1303 & 65.5 & 11.0 & 5.2 & $0 \quad 18$ & 1.9 & 1.2 \\
\hline 13 & January 27, . . . . 1907 & 458 & 65.5 & 11.0 & 5.4 & 1311 & 14.2 & 6.8 \\
\hline 14 & April 5, ....... 1907 & 125 & 58.4 & 13.1 & 4.0 & 2207 & 2.3 & 20.2 \\
\hline 15 & May $26, \ldots \ldots \ldots 1907$ & 1032 & 64.4 & 20.3 & 4. 4 & 1414 & 25.7 & 12.1 \\
\hline 16 & June $29, \ldots \ldots \ldots \ldots 1907$ & 2000 & 60.0 & 8.1 & 4.5 & 1906 & 4.1 & 16.9 \\
\hline 17 & January $8, \ldots \ldots \ldots 1908$ & 2230 & 58.3 & 11.5 & 4.4 & 513 & 4.7 & 6.8 \\
\hline 18 & June $30, \ldots \ldots \ldots 1908$ & 453 & 67.3 & 14.3 & 4.8 & 123 & 13.3 & 16.3 \\
\hline 19 & March $9, \ldots \ldots \ldots 1909$ & 018 & 64.0 & 21.6 & 5.0 & 1702 & 16.0 & 23. 5 \\
\hline 20 & March $15, \ldots \ldots \ldots \ldots 1909$ & 758 & 59.0 & 11.2 & 4.1 & 2314 & 22.0 & 1.5 \\
\hline 21 & February 24, . . . . 1911 & 1813 & 64.6 & 11.5 & 4.2 & 2519 & 16.8 & 10.1 \\
\hline 22 & August $24, \ldots \ldots \ldots 1911$ & 2148 & 60.0 & 5.2 & 4.9 & 106 & 3.3 & 9.1 \\
\hline 23 & December $26, \ldots \ldots .1911$ & 855 & 62.9 & 27.6 & 4.3 & 604 & 19.2 & 17.7 \\
\hline 24 & September 18, . . . 1912 & 2048 & 60.2 & 14.8 & 4. 0 & 804 & 9.4 & 3.3 \\
\hline 25 & July $19, \ldots \ldots \ldots \ldots 1913$ & 1550 & 64.0 & 8.0 & 4.9 & 1601 & 12.9 & 15.4 \\
\hline 26 & August 4, ....... 1913 & 738 & 61.4 & 5.8 & 5.2 & 206 & 0.8 & 18.2 \\
\hline 27 & September 11, ..... 1913 & 234 & 67.5 & 13.5 & 5.0 & 1019 & 9.9 & 6.7 \\
\hline 28 & July $8, \ldots \ldots \ldots \ldots 1917$ & 1441 & 68.9 & 15.6 & 4.0 & 1913 & 2.5 & 11.9 \\
\hline 29 & April $10, \ldots \ldots \ldots 1918$ & 026 & 61.4 & 6.5 & 4.9 & 2821 & 0.1 & 13.4 \\
\hline 30 & August $22, \ldots \ldots \ldots 1918$ & 2022 & 60.6 & 6.0 & 4.0 & 1611 & 1.1 & 19.8 \\
\hline 31 & September 6, ..... 1920 & 446 & 66.9 & 14.0 & 4.5 & 2317 & 25.3 & 22.3 \\
\hline 32 & August $23, \ldots \ldots \ldots 1921$ & 2200 & 55.0 & 15.0 & 4.0 & 2019 & 19.9 & 18.1 \\
\hline 33 & August $23, \ldots \ldots \ldots 1921$ & 2345 & 55.0 & 15.0 & 4.0 & 2021 & 20.0 & 19.8 \\
\hline 34 & June $11, \ldots \ldots \ldots 1922$ & 1244 & 59.6 & 14.5 & 4.3 & 1607 & 8.9 & 12.5 \\
\hline 35 & July $13, \ldots \ldots \ldots \ldots 1922$ & 1858 & 61.6 & 5.7 & 4.2 & 1906 & 15.2 & 15.7 \\
\hline 36 & October 27, ..... 1922 & 510 & 59.7 & 12.0 & 4.2 & 704 & 7.8 & 12.1 \\
\hline 37 & March 23, ....... 1923 & 110 & 61.3 & 5.6 & 4.2 & 600 & 18.5 & 8.6 \\
\hline 38 & May $5, \ldots \ldots \ldots \ldots 1923$ & 309 & 62.4 & 6.0 & 4.2 & 1907 & 5.2 & 0.0 \\
\hline 39 & May $5, \ldots \ldots \ldots \ldots 1924$ & 620 & 61.8 & 5.4 & 4.0 & 119 & 14.5 & 18.3 \\
\hline 40 & January $4, \ldots \ldots \ldots 1926$ & 830 & 69.9 & 29.4 & 4.0 & 1917 & 17.2 & 6.4 \\
\hline
\end{tabular}


TABle 1 (continued)

\begin{tabular}{|c|c|c|c|c|c|c|c|c|}
\hline 1 & 2 & 3 & 4 & 5 & 6 & 7 & 8 & 9 \\
\hline 41 & August $18, \ldots \ldots \ldots 1926$ & 1358 & 65.8 & 28.5 & 5.1 & 923 & 22.4 & 19.8 \\
\hline 42 & October $19, \ldots \ldots 1926$ & $17 \quad 17$ & 57.8 & 7.5 & 4.2 & 1218 & 0.1 & 19.5 \\
\hline 43 & February 25, ...... 1927 & 2000 & 65.5 & 29.0 & 4.2 & 2314 & 21.2 & 14.8 \\
\hline 44 & June $15, \ldots \ldots \ldots \ldots 1927$ & 616 & 61.7 & 4. 4 & 4.3 & 1511 & 18.2 & 6.2 \\
\hline 45 & April 13, ....... 1929 & 805 & 65.3 & 21.6 & 4.1 & 312 & 0.5 & 18.6 \\
\hline 46 & May 23, . . . . . 1929 & 1836 & 57.5 & 7.4 & 4.9 & 1414 & 12.6 & 19.2 \\
\hline 47 & May $29, \ldots \ldots \ldots \ldots 1929$ & 2331 & 57.7 & 7.3 & 4.7 & 2019 & 18.6 & 19.2 \\
\hline 48 & October 26, ...... 1929 & 1344 & 57.0 & 13.5 & 4.2 & 2314 & 3.6 & 7.5 \\
\hline 49 & March $10, \ldots \ldots \ldots 1930$ & 2236 & 62.9 & 17.7 & 4.0 & 1008 & 25.6 & 3.4 \\
\hline 50 & April 3, ........ 1930 & 1747 & 69.0 & 24.0 & 4.2 & 412 & 21.9 & 3.7 \\
\hline 51 & June $10, \ldots \ldots \ldots \ldots 1930$ & $0 \quad 15$ & 61.0 & 5.4 & 4.1 & 1221 & 9.6 & 2.2 \\
\hline 52 & October $31, \ldots \ldots \ldots 1930$ & 2317 & 55.3 & 12.8 & 4.5 & 1001 & 12.4 & 4.1 \\
\hline 53 & November $16, \ldots \ldots .1931$ & 321 & 62.5 & 25.8 & 4.9 & 605 & 7.3 & 12.0 \\
\hline 54 & November $16, \ldots \ldots 1931$ & 1930 & 62.5 & 25.8 & 4.3 & 621 & 8.0 & 3.6 \\
\hline 55 & September 3, ..... 1932 & 1906 & 58.6 & 13.0 & 4.2 & 223 & 0.0 & 5.5 \\
\hline 56 & August $5, \ldots \ldots \ldots 1933$ & 2358 & 59.4 & 13.0 & 4.5 & 1408 & 2.3 & 1.2 \\
\hline 57 & November $2, \ldots \ldots .1934$ & 1640 & 62.1 & 28.0 & 4.0 & 2501 & 16.6 & 10.2 \\
\hline 58 & December $12, \ldots \ldots .1934$ & 2010 & 60.2 & 23.2 & 4.4 & 606 & 13.4 & 4.6 \\
\hline 59 & January $7, \ldots \ldots \ldots \ldots 1935$ & 1732 & 65.0 & 20.2 & 4.0 & 212 & 1.2 & 4.9 \\
\hline 60 & January $11, \ldots \ldots \ldots 1935$ & 2217 & 60.2 & 23.2 & 4.2 & 617 & 5.2 & 6.5 \\
\hline 61 & January 28, . . . . 1935 & 1512 & 65.6 & 11.9 & 4.0 & 2312 & 22.4 & 8.9 \\
\hline 62 & October $10, \ldots \ldots .1935$ & $5 \quad 52$ & 62.5 & 17.1 & 4.0 & 220 & 26.6 & 16.7 \\
\hline 63 & April $5, \ldots \ldots \ldots 1936$ & 2122 & 64.0 & 18.0 & 4.1 & 1319 & 13.1 & 23.4 \\
\hline 64 & March $11, \ldots \ldots \ldots \ldots 1938$ & 1608 & 61.9 & 4.2 & 5.2 & 910 & 0.3 & 20.8 \\
\hline 65 & June $22, \ldots \ldots \ldots \ldots 1939$ & 1411 & 61.4 & 5.0 & 4.0 & 501 & 2.7 & 22.3 \\
\hline 66 & October $9, \ldots \ldots \ldots 1939$ & 1009 & 58.0 & 7.6 & 4.6 & 2603 & 26.0 & 1.5 \\
\hline 67 & January $27, \ldots \ldots \ldots 1941$ & 121 & 61.2 & 5.8 & 4.4 & 2703 & 8.0 & 15.7 \\
\hline 68 & January $4, \ldots \ldots \ldots .1942$ & 2239 & 60.0 & 6.0 & 4.0 & 1713 & 17.8 & 20.8 \\
\hline 69 & November 26, . . . 1942 & 309 & 59.9 & 6.4 & 4.8 & 1713 & 15.0 & 1.3 \\
\hline 70 & August $29, \ldots \ldots \ldots 1943$ & 535 & 59.0 & 6.2 & 4.1 & 2722 & 13.5 & 19.2 \\
\hline 71 & April 24, ........ 1946 & 1745 & 55.4 & 15.6 & 4.3 & 2216 & 20.3 & 12.7 \\
\hline 72 & February 8, . . . . 1947 & 2045 & 62.2 & 8.2 & 4.0 & 1709 & 4.9 & 18.9 \\
\hline 73 & July $22, \ldots \ldots \ldots \ldots 1948$ & 1915 & 55.4 & 15.6 & 4.0 & 1601 & 13.9 & 19.3 \\
\hline 74 & July $23, \ldots \ldots \ldots \ldots 1948$ & 831 & 62.5 & 6.0 & 4.0 & 1614 & 14.5 & 7.5 \\
\hline
\end{tabular}

TABLE 2

Distribution of earthquakes and their energy in Fennoscandia from 1900-1950

\begin{tabular}{l|c|c|c}
\hline Magnitude & $\begin{array}{c}\text { Number of } \\
\text { earthquakes }\end{array}$ & $\begin{array}{c}\text { Summary energy, } \\
\text { in \%\% }\end{array}$ & $\begin{array}{c}\text { Quantity of energy which on an average } \\
\text { accounts for one conventional earthquake, in \%\% }\end{array}$ \\
\hline $5.0-5.4$ & 8 & 56.7 & 7.1 \\
$4.5-4.9$ & 18 & 28.7 & 1.6 \\
$4.0-4.4$ & 48 & 10.0 & 0.2 \\
$3.5-3.9$ & 84 & 3.6 & 0.04 \\
$3.0-3.4$ & 111 & 1.0 & 0.01 \\
\hline
\end{tabular}




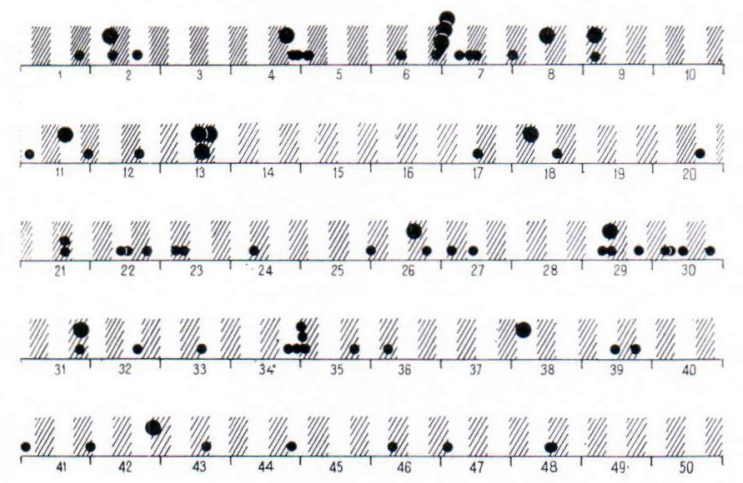

Fig. 2. Strong earthquakes in Fennoscandia (1900-1950). Years of the XX century are on the horizontal line. The lunar orbit perigee is: in the syzygy zones (shading): beyond the syzygy zones (left unshaded). Earthquake magnitudes (M): $4.8-5.4$ or more (large circles): $4.0-$ 4.7 (small circles).

The average synodic age of an earthquake is the time interval (in days) between the date of the earthquake and the last new moon; it is determined by taking the average duration of the synodic month as 29.6 days. In this paper, the difference in the time interval between two real subsequent new moons and the duration of the average synodic month is corrected.

The reduced anomalistic age of the earthquake is the time interval (in days) between the date of the earthquake and the previous moon's passage through its perigee. The duration of the reduced anomalistic age is determined by taking the average duration of an anomalistic month as 27.6 days. For the conversion of the current anomalistic age into the reduced anomalistic age a correction is introduced (sometimes up to some dozens of hours).

For the purpose of uniformity, it is convenient to use the reduced lunar days conjugated by duration with the solar days instead of the lunar days with a duration of 24 hours 50 minutes.

The whole time interval between 1900 and 1950 is divided into two groups of intervals which are equal in total duration (each amounting to 25 years). One of them, i.e. the first group of intervals, corresponds to the conditions under which the new moon or full moon was near the perigee of the lunar orbit. The second group of time intervals corresponds to the conditions under which the new moon or full moon was far from the perigee (Fig. 2).

13 strong earthquakes $(M=4.8-5.4)$ have been recorded within the first group of time intervals, while only 3 strong earthquakes fall within the second group of intervals. On the whole, the amount of seismic energy released by strong earthquakes in the first group of intervals was twice as high as that in the second group of intervals. Thus, with the increase in the tidal efforts (the proximity of the perigee part of the lunar orbit to the syzygy phases) the seismic activity in Fennoscandia is increasing.

The greatest amount of seismic energy (416 $\times$ $10^{18}$ ergs or $77 \%$ ) was released in the regions situated north of the $60^{\circ}$ parallel (the greater part of Norway and Sweden and the whole of Finland).

In Fennoscandia as a whole the main quantity of seismic energy $(81.2 \%)$ was released in the interval between the $28-3(32.9 \%)$ and $9-18$ $(48.3 \%)$ days of the synodic month. Within the other part of the synodic month (3-9 and 1828 days) the frequency of the seismic energy released was 5 times less.

This is a remarkable fact indicating the extremely important role played by the lunar phases (with the mutual location of the Earth, the Moon and the Sun) in the distribution of the seismic energy of this region during the lunar month.

It may be mentioned in passing that the strongest earthquake with a magnitude of $\mathrm{M}=6.5$ (it occured on the 13.7 th day of the synodic month) falls within the interval of the 9-18 days of the synodic month (main maximal released seismic energy in Fennoscandia).

The distribution of the earthquakes as a function of the synodic and reduced anomalistic age is shown in Fig. 3. As can be seen the plots of the strongest earthquakes (with a magnitude of $M \geqslant 4.0$ ) in Fennoscandia fall within narrow zones elongated in a direction extending from 


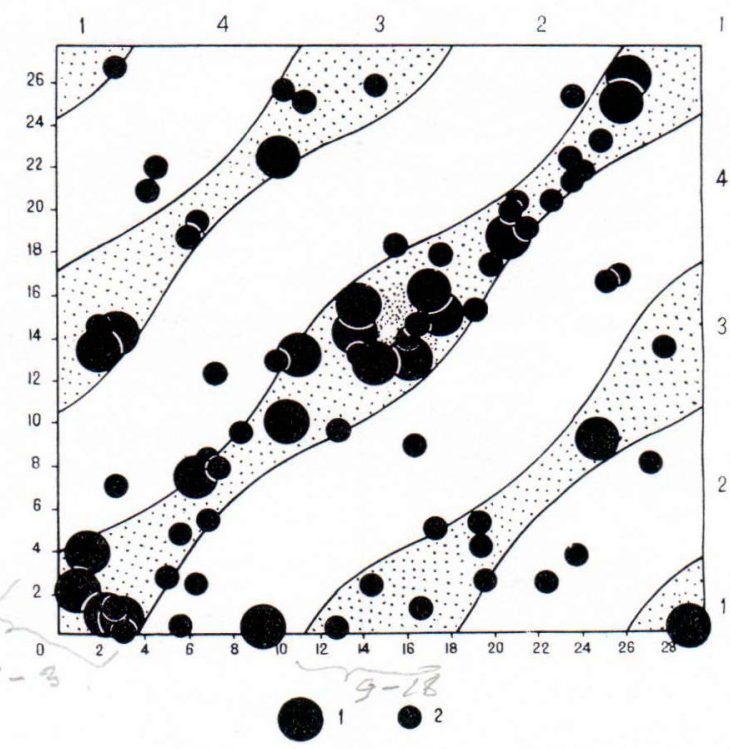

Fig. 3. Distribution of strong earthquakes (with $M \geqslant 4.0$ ) in Fennoscandia from $1900-1950$ as a function of the average synodic and reduced anomalistic age. Days of the average synodic month are on the abscissa. Days of the reduced anomalistic month are on the ordinate. Circles designate earthquakes. Earthquake magnitudies: 1) 4.6-5.4 or more: 2) 4.0-4.5. By dots is shown the time during which cosmic conditions favor the earthquakes.

the lower left corner to the upper corner of the diagram.

56 earthquakes (with a magnitude of $M \geqslant 4$ ) occured in the seismically active zones, whereas only 19 earthquakes occured in the seismically passive belts. If the number of earthquakes in the seismically passive belts (numbers 2 and 4 ) is recalculated to one hundred percent, then the

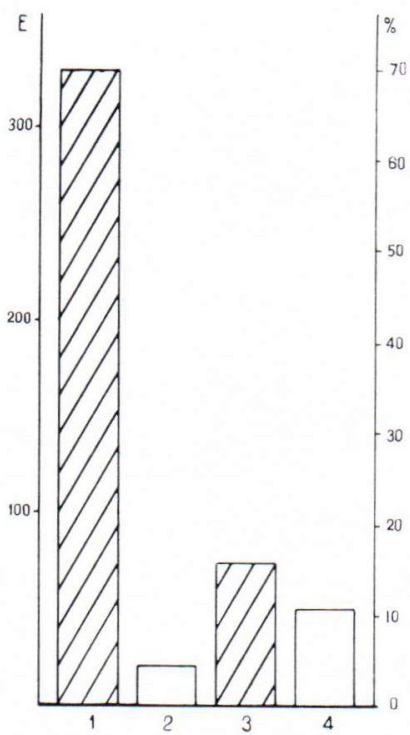

Fig. 4. Distribution of energy of all earthquakes in Fennoscandia according to seismically active zones (shading) and seismically passive belts (is left unshaded).

1 and 3 - seismically active zones: 2 and 4 - seismically passive belts. E - energy, in $10^{18}$ ergs (on the right is energy in percent).

seismically active zones (numbers 1 and 3) show an increase of $295 \%$ (Table 3).

Especially interesting is the distribution of earthquake energy (Table 3). In seismically active zones the release of seismic energy increased 6 times $(641 \%)$ as much as it did in seismically passive belts. This is especially obvious for the first seismically active zone, where the energy of the earthquakes exceeded that of the earthquakes in the seismically passive zone $7-18$ times (Fig. 4).

TABLE 3

Distribution of strong earthquakes $(M \geqslant 4.0)$ in Fennoscandia (1900-1950) and their energy in seismically passive betls and seismically active zones

\begin{tabular}{|c|c|c|c|c|c|c|c|}
\hline \multirow{2}{*}{$\begin{array}{c}\text { Belt, } \\
\text { zone }\end{array}$} & \multicolumn{2}{|c|}{$\begin{array}{l}\text { Seismically } \\
\text { passive belt }\end{array}$} & \multicolumn{2}{|c|}{$\begin{array}{l}\text { Seismically } \\
\text { active zone }\end{array}$} & \multirow{2}{*}{$\begin{array}{c}\begin{array}{c}\text { Seismically } \\
\text { passive belts }\end{array} \\
2+4\end{array}$} & \multirow{2}{*}{$\begin{array}{c}\begin{array}{c}\text { Seismically } \\
\text { active zones }\end{array} \\
1+3\end{array}$} & \multirow{2}{*}{$\begin{array}{l}\text { In the active } \\
\text { zones as } \\
\text { compared } \\
\text { to the passive } \\
\text { belts, } \% \%\end{array}$} \\
\hline & 2 & 4 & 1 & 3 & & & \\
\hline Number of earthquakes ... & 10 & 9 & 39 & 17 & 19 & 56 & 295 \\
\hline $\begin{array}{l}\text { Eriergy of earthquakes } \\
\quad \times 10^{18} \text { ergs, } \ldots \ldots \ldots \ldots \ldots \\
\% \% \ldots \ldots \ldots \ldots \ldots\end{array}$ & $\begin{array}{r}20.3 \\
3.9 \\
\end{array}$ & $\begin{array}{r}49.3 \\
9.7\end{array}$ & $\begin{array}{r}373.5 \\
72.4\end{array}$ & $\begin{array}{l}72.6 \\
14.0\end{array}$ & $\begin{array}{l}69.6 \\
13.6\end{array}$ & $\begin{array}{r}446.1 \\
86.4\end{array}$ & 641 \\
\hline
\end{tabular}




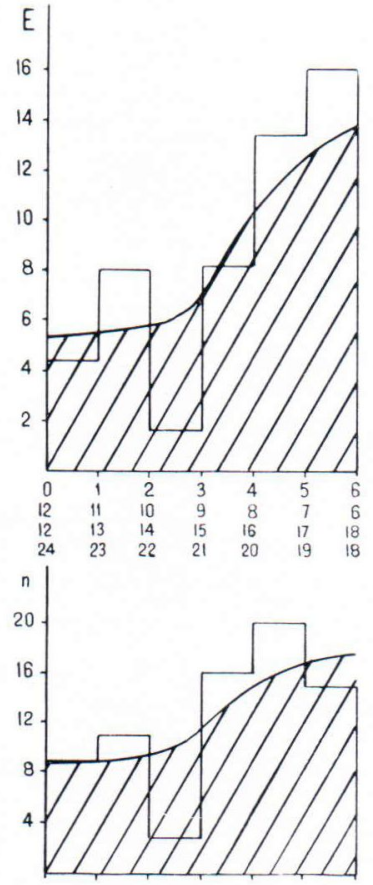

Fig. 5. Distribution during the lunar day of strong earthquakes (with $M \geqslant 4$ ) and their energy in Fennoscandia (1900-1950). n - number of earthquakes: $\mathrm{E}$ - energy of earthquakes, in $10^{18}$ ergs: curve shows the change in seismic energy $\left(E \times 10^{18}\right.$ ergs $)$ by twice-sliding threehour periods.

The increase of several hundred percent (500$1000 \%$ or more) in the energy released by earthquakes as related to the variation of values of the tide-generating forces is a visual and undisputable demonstration of the genetic connection between seismic activity and tide-forming forces (Tamrazyan, 1968).

The distribution of earthquakes in Fennoscandia as related to local reduced lunar time is shown in Fig. 5.

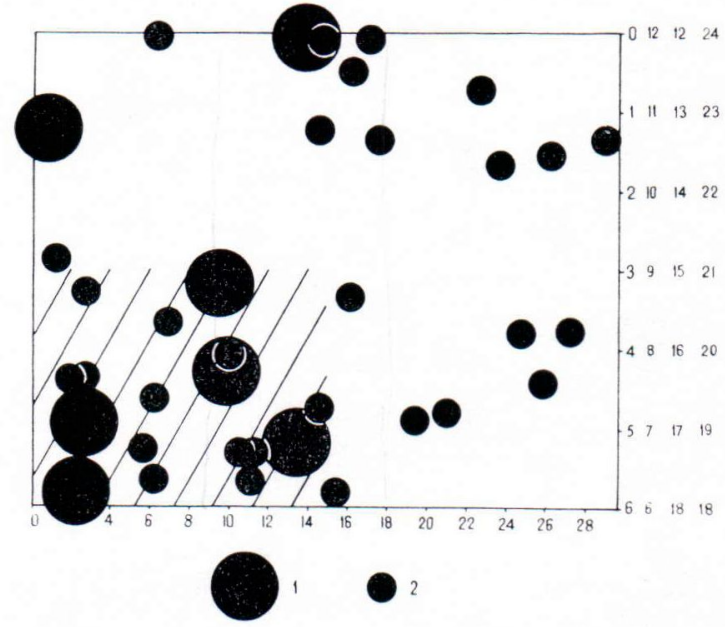

Fig. 6. Distribution of strong earthquakes in Fennoscandia by hours of the reduced lunar days (counted from the moment of the upper culmination of the Moon) and simultaneously in connection with their synodic age $(1900-1950)$.

Eearthquake magnitude (M): 1) $5.1-5.4$ or more: 2) $4.3-5.0$.

The distribution of strong earthquakes as related to local lunar time and their synodic age is shown in Fig. 6. The increase in the number of strong earthquakes and especially in their energy, depicted in the lower left part of Fig. 6, is striking. Here, in comparison with the rest of the figure, the frequency of the earthquakes is twice as high and their energy is 5 times greater.

The almost distinct maximum of the strong earthquakes in certain sections of this figure indicates the role of cosmic influences on the period of intense seismic activity in Fennoscandia. The above correlations testify to the influence of cosmic conditions in triggering off the energy released at earthquake foci.

\section{REFERENCES}

BÅTH, M. (1956) An earthquake Catalogue for Fennoscandia for the years 1891-1950, Stockholm.

Tamrazyan, G. P. (1966) Time of origination of earthquakes in the Kuril-Adjoint-to-Kamchatka Region and the local Time (Lunar, Solar). Journal of Physics of the Earth, Vol. 14, No. 2, 41-48, Japan.

- (1968) Principal regularities in the distribution of major earthquakes relative to solar and lunar tides and other cosmic forces. Icarus (International Journal of the Solar system), Vol. 9, No. 3, 574-592. USA.

- (1968) Seismicity in Finland against a background of the cosmic conditions. Bull. Geol. Soc. Finland, 40, 113-116, Finland.

- (1969) Seismicity of Norway in relation to cosmic conditions. Norsk Geologisk Tidsskrift. Vol. 49, No. 1, 81-86, Norway.

- (1969) Seismic anomalies and the dynamic evolution of the Earth's Crust and Upper Mantle. Icarus (International Journal of the Solar System), Vol. 10, No. 1, 164-168. USA-Great Britain

Manuscript received, December 30, 1969. 